\title{
Food avoidance does not improve childhood eczema
}

\author{
KL Hon *, MD, FCCM, TF Leung, MD, FRCPCH \\ Department of Paediatrics, The Chinese University of Hong Kong, Prince of Wales Hospital, Shatin, Hong Kong \\ *Corresponding author: ehon@cuhk.edu.hk
}

Hong Kong Med J 2015;21:574-5

DOI: 10.12809/hkmj154618

Childhood eczema is one of the most common atopic diseases associated with chronicity and often a relapsing course. ${ }^{1,2}$ The disease may 'march' to involve the airways. ${ }^{3}$ There are many myths and fallacies in its management, ${ }^{4-6}$ and food is often implicated too readily in its pathophysiology. ${ }^{7-9}$ Hence one aspect in management is to identify the underlying allergen(s) with the belief that their avoidance will prevent its occurrence, cure the disease, or at least ameliorate its severity. ${ }^{7-10}$ In a city like Hong Kong where myths and fallacies abound, food avoidance and dietary supplementation has become all the more a vogue. ${ }^{7,8,11}$

It is believed that food allergens can mediate the inflammatory process of eczema by immediate (type I, immunoglobulin [Ig] E-mediated), delayed (type IV, cell-mediated), and even non-immediate, non-delayed hypersensitivity processes..$^{811-13}$ Most children do not have a genuine multi-food allergy, and only a few common food allergens are involved. In Hong Kong, parents generally think doctors do not advocate food avoidance, and are insistent that their atopic children have multiple food allergies. ${ }^{7,8}$ In infancy, many parents believe that cow's milk protein is the principal food allergen. Hence anxious non-breastfeeding mothers will change milk formula from one brand or type to another, often within a very short time span, and see no benefit as a result of milk avoidance. Even among local preschool children, cow's milk together with shellfish, egg, and peanut were among the leading foods that caused adverse food reactions. ${ }^{14}$ In toddlers and older children, parents may request skin and blood tests to search for the often elusive food allergens. ${ }^{7,8,11}$

Food-specific IgG testing has recently become fashionable. Commercial enzyme-linked immunosorbent assay kits are used and test many ethnic-specific food items with tiny amounts of blood. ${ }^{8}$ The results are often positive for multiple foods. ${ }^{8}$ Based on these results, more food items will be avoided on top of the already-long list of food that these parents will customarily avoid, albeit without any appreciable benefits. Testing of IgG4 to foods is considered irrelevant for the laboratory workup of food allergy or intolerance and should not be performed in case of food-related complaints. ${ }^{10,12,13,15,16}$ Hon et $\mathrm{al}^{8}$ showed that patients with lower casein IgG $(\mathrm{P}=0.041)$, milk $\operatorname{IgG}(\mathrm{P}=0.037)$, or whey IgG $(\mathrm{P}=0.014)$ had improved eczema SCORAD (SCORing of Atopic Dermatitis) following dietary advice, but it was unclear whether certain foods that have low titres of IgG should be avoided. Nevertheless, IgG to foods has no clinical value in the diagnosis of food allergy and is not recommended by professional bodies. ${ }^{10,15,16}$ Levels of food IgG do not seem to correlate with any clinical parameters in eczema. ${ }^{8}$ High levels of IgG4 antibodies to foods during infancy are associated with tolerance to corresponding foods later in life. ${ }^{17}$ Thus high IgG may even be beneficial, not detrimental.

In addition to food avoidance, many of these anxious parents often have 'co-morbidities' of 'hearsay' syndrome, or 'Mr Cheung and Mrs Lee syndrome' (張三李四綜合症), 'steroid phobia' (類 固醇恐懼症), 'in-search-of-cure syndrome’ (斷尾、 治癒), 'fear of western medicine' (西藥恐懼症), and love of complementary and alternative medicine. ${ }^{18-21}$

$\mathrm{Du}$ Toit et $\mathrm{al}^{22}$ recently demonstrated that early peanut exposure is associated with a reduced risk of peanut allergy. This resembles the Chinese concept of 'poison-for-poison' (以毒攻毒) that believes desensitisation can be achieved if the immune system is exposed early to a culprit allergen. The fallacy of food allergy and its pan-avoidance based on exhaustive testing should be removed from the minds of parents instead of from their children's diet.

In paediatrics, a balanced diet for growth is advocated. Worries about food allergies also adversely affected parental quality of life. ${ }^{23}$ How should we desensitise parents to avoid less food? Management includes a detailed history with physical examination and focused investigations (問聞望切) to document whether a particular food triggers symptoms of allergy such as gastrointestinal, eczema or asthma flare, and whether avoidance ameliorates these symptoms. A specific diagnosis can then be confirmed and treatment discussed (辨証論治). ${ }^{7,10,12,13}$

Perhaps the following hymn, modified from the 7th-century Buddhist's chant, may help eliminate parental anxiety together with their misguided beliefs about diet. 論 戒而不善 食物本無害 戒口亦非愚 ( 難 ) 本來無關係 何必惹愁哀 


\section{References}

1. Leung AK, Hon KL, Robson WL. Atopic dermatitis. Adv Pediatr 2007;54:241-73.

2. Hon KL, Yong V, Leung TF. Research statistics in atopic eczema: what disease is this? Ital J Pediatr 2012;38:26.

3. Hon KL, Wang SS, Leung TF. The atopic march: from skin to the airways. Iran J Allergy Asthma Immunol 2012;11:737.

4. Leung TN, Chow CM, Chow MP, et al. Clinical guidelines on management of atopic dermatitis in children. Hong Kong J Paediatr 2013;18:96-104.

5. Leung TN, Hon KL. Eczema therapeutics in children: what do the clinical trials say? Hong Kong Med J 2015;21:251-60.

6. Hon KL, Leung TF, Ching G, et al. Patterns of food and aeroallergen sensitization in childhood eczema. Acta Paediatr 2008;97:1734-7.

7. Hon KL, Leung TF, Lam MC, et al. Eczema exacerbation and food atopy beyond infancy: how should we advise Chinese parents about dietary history, eczema severity, and skin prick testing? Adv Ther 2007;24:223-30.

8. Hon KL, Poon TC, Pong NH, et al. Specific IgG and IgA of common foods in Chinese children with eczema: friend or foe. J Dermatolog Treat 2014;25:462-6.

9. Hon KL, Wang SS, Wong WL, Poon WK, Mak KY, Leung TF. Skin prick testing in atopic eczema: atopic to what and at what age? World J Pediatr 2012;8:164-8.

10. Muraro A, Werfel T, Hoffmann-Sommergruber K, et al. EAACI food allergy and anaphylaxis guidelines: diagnosis and management of food allergy. Allergy 2014;69:1008-25.

11. Hon KL, Chan IH, Chow CM, et al. Specific IgE of common foods in Chinese children with eczema. Pediatr Allergy Immunol 2011;22:50-3.

12. NIAID-Sponsored Expert Panel, Boyce JA, Assa'ad A, Burks AW, et al. Guidelines for the diagnosis and management of food allergy in the United States: report of the NIAIDsponsored expert panel. J Allergy Clin Immunol 2010;126(6 Suppl):S1-58.
13. Stapel SO, Asero R, Ballmer-Weber BK, et al. Testing for IgG4 against foods is not recommended as a diagnostic tool: EAACI Task Force Report. Allergy 2008;63:793-6.

14. Leung TF, Yung E, Wong YS, Lam CW, Wong GW. Parentreported adverse food reactions in Hong Kong Chinese pre-schoolers: epidemiology, clinical spectrum and risk factors. Pediatr Allergy Immunol 2009;20:339-46.

15. Carr S, Chan E, Lavine E, Moote W. CSACI Position statement on the testing of food-specific IgG. Allergy Asthma Clin Immunol 2012;8:12.

16. Sampson HA, Aceves S, Bock SA, et al. Food allergy: a practice parameter update-2014. J Allergy Clin Immunol 2014;134:1016-25.e43.

17. Tomicić S, Norrman G, Fälth-Magnusson K, Jenmalm MC, Devenney I, Böttcher MF. High levels of IgG4 antibodies to foods during infancy are associated with tolerance to corresponding foods later in life. Pediatr Allergy Immunol 2009;20:35-41.

18. Hon KL, Leung TF, Yau HC, Chan T. Paradoxical use of oral and topical steroids in steroid-phobic patients resorting to traditional Chinese medicines. World J Pediatr 2012;8:2637.

19. Hon KL, Luk DC, Leong KF, Leung AK. Cupping therapy may be harmful for eczema: a PubMed search. Case Rep Pediatr 2013;2013:605829.

20. Hon KL, Tsang YC, Pong NH, et al. Correlations among steroid fear, acceptability, usage frequency, quality of life and disease severity in childhood eczema. J Dermatolog Treat 2015 Apr 20:1-8. Epub ahead of print.

21. Hon KL, Chan BC, Leung PC. Chinese herbal medicine research in eczema treatment. Chin Med 2011;6:17.

22. Du Toit G, Roberts G, Sayre PH, et al. Randomized trial of peanut consumption in infants at risk for peanut allergy. $\mathrm{N}$ Engl J Med 2015;372:803-13.

23. Leung TF, Yung E, Wong YS, Li CY, Wong GW. Qualityof-life assessment in Chinese families with food-allergic children. Clin Exp Allergy 2009;39:890-6. 